\title{
QUALITY OF ORGANIC BANANA PRODUCED IN THE SEMIARID REGION OF MINAS GERAIS, BRAZIL ${ }^{1}$
}

\author{
ARIANE CASTRICINI ${ }^{2}$, MARIO SÉRGIO CARVALHO DIAS ${ }^{2}$, \\ MARIA GERALDA VILELA RODRIGUES ${ }^{2}$, POLYANNA MARA DE OLIVEIRA ${ }^{3}$
}

\begin{abstract}
The northern semiarid region of Minas Gerais is an important producer of irrigated Prata-Anã banana variety, which is highly susceptible to fusarium wilt. The organic cultivation of resistant varieties may be an phytosanitary alternative, also adding value to fruits. This study aimed to characterize banana varieties produced in organic system based on chemical and physical assessments at post-harvest. Prata-Anã, BRS Platina, Fhia-18, BRS Conquista and BRS Tropical varieties were characterized at the point of harvest (green) and mature (stage six of maturation), by chemical and physical assessments. At the point of harvest, BRS Conquista and BRS Tropical banana varieties had more intense green skin color. 'BRS Conquista' presented lower fresh weight, shorter length and diameter than the other varieties. BRS Platinum variety had more fruit fresh mass, length and diameter. Mature Prata-Anã, BRS Platina, Fhia-18, BRS Conquista and BRS Tropical banana varieties showed no difference in soluble solids, $\mathrm{pH}$, titrable acidity and ratio; BRS Platina variety had more intense yellow skin color and lower pulp/skin ratio. Greater dropping resistance occurred in BRS Conquista variety and BRS Tropical was less resistant. Prata-Anã banana variety showed higher firmness. Banana varieties differed more by the physical characteristics (skin color, size, dropping resistance, firmness and pulp/skin ratio) in relation to chemical characteristics.
\end{abstract}

Index Terms: Musa spp., varieties, postharvest.

\section{QUALIDADE DE BANANA ORGÂNICA PRODUZIDA NO SEMIÁRIDO DE MINAS GERAIS}

RESUMO - A região norte de Minas Gerais, semiárida, é importante produtora de banana 'Prata-Anã' irrigada, cultura altamente suscetível ao mal-do-panamá. O cultivo orgânico de variedades resistentes pode ser uma alternativa fitossanitária, além de agregar valor aos frutos. Objetivou-se caracterizar, em póscolheita, variedades de banana produzidas em sistema orgânico, com base em avaliações químicas e físicas. As variedades Prata-Anã, BRS Platina, Fhia-18, BRS Conquista e BRS Tropical foram caracterizadas no ponto de colheita (verdes) e maduras (estádio seis de maturação), por avaliações químicas e físicas. No ponto de colheita, bananas 'BRS Conquista' e 'BRS Tropical' tiveram a cor da casca verde mais intensa. A 'BRS Conquista' apresentou menor massa fresca, menor comprimento e diâmetro do fruto em relação às demais variedades. A 'BRS Platina' produziu frutos com maior massa fresca, comprimento e diâmetro. Bananas 'Prata-Anã', 'BRS Platina', 'Fhia-18', 'BRS Conquista', e 'BRS Tropical', maduras, não apresentaram diferença no teor de sólidos solúveis, $\mathrm{pH}$, acidez titulável e ratio; a 'BRS Platina' obteve a casca com tonalidade amarela mais intensa e menor relação polpa/casca. Maior resistência ao despencamento ocorreu em 'BRS Conquista', e a 'BRS Tropical' foi menos resistente. A banana 'Prata-Anã' apresentou maior firmeza. As variedades diferiram mais pelas características físicas (cor da casca, tamanho, resistência ao despencamento, firmeza e relação polpa/casca) em relação às químicas.

Termos para Indexação: Musa spp., variedades, pós-colheita.

\footnotetext{
${ }^{1}$ (Paper 236-15). Received on October 20, 2015. Accepted February 17, 2016

${ }^{2}$ Agronomic Engineer, PhD, Researcher at Epamig Norte de Minas Gerais, Brazil, CEGR, Rodovia MGT 122, Km 155, Nova Porteirinha - MG. Fapemig Fellowship. Email: ariane@epamig.br; mariodias@epamig.br; magevr@epamig.br

${ }^{3}$ Agricultural Engineer, PhD, Researcher at Epamig Norte de Minas Gerais, Brazil, CEGR, Rodovia MGT 122, Km 155, Nova Porteirinha - MG. Fapemig Fellowship. Email: polyanna.mara@epamig.br.
} 


\section{INTRODUCTION}

According to IBGE (2015), the national banana production in 2014 was $7,138,437$ tons. The southeast region is responsible for $31.82 \%$ and Minas Gerais for $9.97 \%$ of the total produced in the country. Banana cultivation is an important economic activity and job generator in the semiarid region of northern Minas Gerais, where the cultivation of irrigated Prata-Anã banana variety under a conventional system is predominant.

Panama disease hinders and even prevents the cultivation of 'Prata-Anã' banana plant in some properties of the region due to cultivar susceptibility and soil conductivity. This disease does not have chemical control and the use of resistant varieties can be an alternative, since fruits present characteristics acceptable by the consumer market.

The National Banana Improvement Program coordinated by "Embrapa Mandioca and Fruticultura" studies the behavior of different banana varieties resistant to diseases such as BRS Platina (AAAB), which is a Prata-type hybrid (Prata-Anã x M53) of small to medium size, resistant to yellow and black sigatokas and Panama disease (DONATO et al., 2006; CORDEIRO et al., 2006). Fhia-18 is a tetraploid (AAAB) hybrid of 'Prata-Anã', which is also resistant to black sigatoka, moderately susceptible to yellow sigatoka and tolerant to Panama disease (COSTA et al., 2012). Another variety also resistant to diseases is BRS Conquista, which belongs to the AAB genomic group, 'Conquista' cultural subgroup. It was obtained from natural mutation (variation) in a plant population of the Thap Maeo cultivar (PEREIRA; GASPAROTTO, 2008). 'BRS Tropical' has AAAB genetic group, similar to Maçã variety and resistant to yellow sigatoka, moderately resistant to nematodes, tolerant to Panama disease and susceptible to moko (RAMOS et al. 2009).

Fruit quality can be easily influenced by the place where it is produced, by cultural practices and type of management. The sensory characteristics can be altered according to the soil-climatic conditions, influencing the chemical composition, especially in the production of acids, sugars and phenolic compounds (TEIXEIRA et al., 2011). Thus, fruits produced in organic system, in addition to being free of residues of agrochemicals, may also present physical and chemical composition distinctions. Of the many questions about organic foods, the most important are those related to productivity and sensorial quality characteristics, with references to the reduced size of fruits and increased sugar contents, when fruits are obtained in an organic way (BORGUINI; TORRES, 2006). Ribeiro et al. (2012) verified that the chemical attributes of bananas are little affected by the cultivation system and that organic management allows greater chemical distinction of cultivars.

Many results on the quality of bananas produced in conventional crops have been reported; however, information on the quality of Prata-Anã, BRS Platina, Fhia-18, BRS Conquista and BRS Tropical banana varieties produced in organic systems is scarce or even non-existent.

The characterization of fruits at the point of harvest, that is, still green, but physiologically developed, allows identifying differences related to each variety, making it possible to obtain information that may guide harvesting, internal transport, packaging, external transport based on susceptibility to mechanical damage, dropping resistance, fruit size, coloring, etc., directing them according to market requirements. The final commercialization by retailers usually takes place in stages 5 and 6 of the Loesecke scale (1950), which, although old, is still used in the classification of fruits by the "Companhia de Entrepostos e Armazéns Gerais de São Paulo (CEAGESP)".

The aim of this study was to characterize banana varieties produced in organic system based on chemical and physical evaluations at the postharvest period.

\section{MATERIAL AND METHODS}

In the Post-Harvest Laboratory of the Empresa de Pesquisa Agropecuária de Minas Gerais (EPAMIG) located in the Experimental Field of Gorutuba in Nova Porteirinha-MG, the following banana varieties were evaluated: Prata-Anã, BRS Platina, Fhia-18, BRS Conquista and BRS Tropical produced at the Experimental Field of Mocambinho, belonging to Epamig, is located in northern Minas Gerais, irrigated perimeter of Jaíba, semiarid region.

The conduction of the area followed organic production standards (BRAZIL, 2011, 2014). The soil was prepared with plowing and harrowing. Fertilizations were done in the planting hole and top-dressing with the doses defined according to the nutritional plant requirements, availability of nutrients in the soil and in the leaf tissue. Topdressing started 30 days after the transplanting of seedlings, carried out every 45 days until the end of the crop cycle. The following were used as sources of nutrients: cattle manure to provide N (14.4 ton / ha / year) and increase soil CTC; sul-po-mag, 22\% 
$\mathrm{K}_{2} \mathrm{O}, 22 \% \mathrm{~S}$ and $11 \% \mathrm{Mg}$, obtained from the crushing of langbeinite (2.4 ton / ha / year); bioactive organicmineral, with $12 \% \mathrm{P}_{2} \mathrm{O}_{5}$ and $\mathrm{Ca}$, obtained from the mixture of $40 \%$ bovine manure, $60 \%$ phosphate rock and P solubilizing bacterium (3.3 tons / ha / year); and FTE BR10, supplier of micronutrients $(50 \mathrm{~g} /$ pit in planting).

Fruits were harvested at the commercial maturity point: fruits with maximum growth, still slightly bent, and with a completely green skin, that is, at stage two of the Loesecke scale (LOESECKE, 1950), used by Ceagesp classification (CEAGESP, 2006). After harvesting, fruits were characterized at the point of harvest (green) and when ripe. Fruits were considered ripe at maturation stage six, according to the same scale. Fruits remained in the post-harvest laboratory, at room temperature (25 $\pm 2{ }^{\circ} \mathrm{C}$ ), for approximately one week until natural maturation.

The common evaluation for both maturation stages was: skin color determined using Minolta Colorimeter, model Chroma meter CR 400, L C H system. The colorimeter expresses color using three parameters: (a) luminosity $(\mathrm{L} *)$, which ranges from 0 (black) to 100 (white); (b) chromaticity or color purity $\left(\mathrm{C}^{*}\right)$, whose relatively lower values represent impure colors (grayish), and higher, more pure colors, and (c) hue or true color angle $\left({ }^{\circ} \mathrm{Hue}\right)$, ranging from $0^{\circ}$ to $360^{\circ}$, in which angle $0^{\circ}$ corresponds to the red color, $90^{\circ}$ to the yellow color, $180^{\circ}$.

At the point of harvest, fresh weight $(\mathrm{g})$ obtained by digital weighing; length $(\mathrm{cm})$ measured with tape measure in the external fruit curvature between the insertion of the peduncle and the opposite end and diameter $(\mathrm{mm})$ obtained with digital caliper in the median region of fruits were evaluated.

Evaluations of dropping resistance (PIMENTEL et al., 2010), fruit firmness (N) obtained in digital penetrometer, pulp pH, soluble solids ( ${ }^{\circ} \mathrm{Brix}$ ) and titratable acidity (\%) (INSTITUTO ADOLFO LUTZ, 1987), pulp / skin ratio (soluble solids / titratable acidity) were conducted only on mature fruits (stage 6).

Statistical analysis was performed using the Saeg software (2007), preceded by the normality test (Lilliefors). A completely randomized design with three replicates of four fruits per plot was used. In order to reduce the normal variation among fruits of the same bunch to compose the first, second and third repetitions, fruits of the second, third and fourth bunches, respectively, of each variety were used. A general variance analysis was performed for the study variables in order to identify significant differences in the characteristics of varieties. Significant effects were studied by the Tukey test at $5 \%$ probability.

\section{RESULTS AND DISCUSSION}

All variables evaluated at the point of harvest and in mature fruits had normal distribution, according to the Lilliefors test, since the values calculated in the test were lower than 0.220 .

Fruits at the point of harvest (green) Significant difference for chroma $\left(\mathrm{C}^{*}\right)$, hue angle, fresh weight, length and diameter among the different varieties studied was observed (Table 1). The luminosity of the fruit skin color was not different among varieties, with average value of 59.3 (Table 2).

The average values of variables evaluated at the point of harvest are shown in Table 2. The Chroma values that infer on pigment saturation or color purity was higher in the skin of 'Prata-Anã' and 'BRS Tropical' fruits, which did not differ from 'BRS Conquista'. Lower chroma values occurred in BRS Platina and Fhia-18 varieties, indicating that these fruits exhibit skin with less pigment saturation that make up its green color. According to Oliveira et al. (2010a), the lower the chroma value, the less pure is the color, making it difficult to differentiate among hues. Thus, the increase in chroma values indicates along with the evolution of the hue angle, tendency for maturation, causing the coloration to become more homogeneous (less tonality and increased color purity).

'BRS Conquista' fruits showed more intense green color of the skin, a trend evidenced by the higher ${ }^{\circ}$ hue, but with no significant difference between Fhia-18 and Tropical BRS varieties (Table 2). The green color was less intense in BRS Platina and Prata-Anã varieties, which are characterized by presenting less intense green skin color than BRS Conquista variety at the point of harvest. Both the degradation of chlorophylls and the synthesis of carotenoids are processes modulated by ethylene during ripening, but the color shade can also be a genetic characteristic, giving different nuances to the fruit skin (CASTRICINI et al., 2015), in addition to being an indication of the point of harvest.

'BRS Platina' and 'Fhia-18' fruits had higher fresh mass and length, but BRS Platina variety presented fruits with larger diameter. According to Lédo et al. (2008), Fhia-18 variety presented excellent agronomic characteristics, being an alternative to Prata-Anã cultivar. Of the five varieties studied, BRS Conquista fruits were the smallest, lightest and with the smallest diameter. In relation to mass and length, Prata-Anã and BRS Tropical varieties had intermediate mean values; however, the diameter of Prata-Anã variety is lower than that of Tropical BRS variety (Table 2). 'BRS Tropical' fruits had an 
average fresh mass of $120.62 \mathrm{~g}$, being lower than that reported by Ribeiro et al. (2012), which was 150.91 $\mathrm{g}$, also produced in organic farming system. Carvalho et al. (2011) verified the following characteristics in 'BRS Tropical' fruits: $10.55 \mathrm{~cm}$ in length, $34.20 \mathrm{~mm}$ in diameter, $23.67^{\circ} \mathrm{Brix}$ (in completely yellow fruits with brown spots) and good sensory acceptability.

Prata-Anã, BRS Platina and Fhia-18 varieties are Prata-type fruits and according to the Cesgesp Classification Standards (CEAGESP, 2006), the fruits of the present work belong to class 18 (length greater than $18 \mathrm{~cm}$ and up to $22 \mathrm{~cm}$ ) and to the extra category (minimum diameter of $34 \mathrm{~mm}$ ). Grouping into classes guarantees the homogeneity of size among fruits of the same batch. Oliveira et al. (2010b) found that mature 'Prata-Anã' bananas had smaller length and diameter than 'BRS Platina'.

BRS Conquista and BRS Tropical varieties are Maçã type and the fruits are classified as classes 12 and 15 , respectively, according to Ceagesp (CEAGESP, 2006). Regarding the category, the fruits of both varieties are classified as extra (minimum diameter of $32 \mathrm{~mm}$ ). According to Oliveira et al. (2013), the characteristics that define fruit size, such as length, diameter and mass, are important attributes for genetic improvement, since they interfere in the consumer's preference and affect the fruit yield, both at the time of harvest and in its industrial use.

Matsuura et al. (2004) found that the ideal banana fruit should have medium size (12 to $15 \mathrm{~cm}$ ) or large ( 16 to $19 \mathrm{~cm})$ and intermediate diameter $(2.6$ to $3.0 \mathrm{~cm}$ ).

Ripe fruits (skin color at stage 6) - There was a significant difference among varieties for luminosity and skin hue angle, dropping resistance, firmness and pulp / skin ratio. Chroma, soluble solids, $\mathrm{pH}$, titratable acidity and ratio of mature fruits did not differ among varieties (Table 3 ). The mean values were: chroma of $48.19,11.96^{\circ} \mathrm{Brix}, \mathrm{pH} 4.58$, titratable acidity of $0.31 \%$ and ratio of 39.1 (Table 4), similar to those found by Carvalho et al. (2011), Oliveira et al. (2013), Castricini et al. (2015).

Luminosity (L*) of 'BRS Conquista' banana skin was higher than that of 'BRS Platina', and no statistical difference with the other varieties was observed (Table 4). Higher luminosity values indicate that the predominant color, in this case yellow, is lighter or brighter, and may be characteristic of each variety.

The hue angle that indicates if the color shade is within the yellow color range and according to the mean values shown in Table 4, the yellow color of the 'BRS Platina' banana skin is more intense but statistically equal to the color of Prata-Anã and
Fhia-18 varieties. 'BRS Tropical' fruits presented less intense yellow skin color. According to the CIELAB system, if the angle is between $0^{\circ}$ and $90^{\circ}$ and the larger the angle, the more yellow the fruit is (TRIGO et al., 2012).

The dropping resistance was higher in BRS Conquista variety $(17.11 \mathrm{~N})$, being statistically equal between Prata-Anã (3.4 N), BRS Platina (4.05 N) and Fhia-18 (5.7 N). Lower resistance occurred in 'BRS Tropical' fruits $(1.28 \mathrm{~N})$. However, in spite of the greater resistance of 'BRS Conquista' fruits, all varieties of this study are considered susceptible to dropping, as defined by Oliveira et al. (2013).

'Prata-Anã' fruits had greater firmness, which is a variety characteristic: $(5.8 \mathrm{~N})$ in comparison to the other varieties: $3.52 \mathrm{~N}, 3.24 \mathrm{~N}, 4.15 \mathrm{~N}$ and $3.15 \mathrm{~N}$, for BRS Platina, Fhia-18, BRS Conquista and Tropical BRS varieties, respectively (Table 4). According to Oliveira et al. (2013), 'Prata-Anã' fruits were firmer compared to 'BRS Platina' fruits in almost all maturation stages at $25^{\circ} \mathrm{C}$. Pimentel et al. (2010) found pulp firmness values for 'PrataAnã' fruits higher than those of 'BRS Platina' throughout the maturation period at $22^{\circ} \mathrm{C}$. Carvalho et al. (2011) verified that BRS Tropical cultivar had greater firmness compared to Thap Maeo and Caipira cultivars.

The mean pulp / skin ratio values of mature fruits are presented in Table 4. The lowest ratio was observed for 'BRS Platina' fruits, which did not differ from 'Fhia-18' fruits, unlike 'BRS Tropical' fruits, which had higher pulp / skin ratio. According to Damatto Jr. et al. (2005), with maturation, fruits will have greater pulp percentage, since the green skin loses more water than the pulp this period. In addition to losing water to pulp, the banana skin loses water to the environment by perspiration, resulting in increased pulp / skin ratio during maturation.

The studied varieties presented peculiarities regarding the physical and chemical characteristics evaluated; some of them similar to Prata-Anã variety used as standard of comparison, others not similar. However, the results obtained serve to guide the farmer in the case of the option for these varieties, which is a viable alternative of coexistence with the main diseases affecting banana crops and likely to be conducted in an organic system. 
TABLE 1 - Analysis of variance for variables of organic banana varieties at the point of harvest. Nova Porteirinha - MG, 2014.

\begin{tabular}{c|ccccccc}
\hline Source of variation & D. F. & L* $^{*}$ & C $^{*}$ & ohue & Fresh mass & Length & Diameter \\
\hline Variety & 4 & $7.83^{\text {ns }}$ & $7.56^{*}$ & $3.43^{*}$ & $7271.07^{*}$ & $31.21^{*}$ & $57.76^{*}$ \\
Residue & 10 & 4.31 & 0.52 & 0.31 & 11.97 & 0.96 & 0.54 \\
\hline V.C. (\%) & & 3.5 & 1.7 & 0.5 & 7.5 & 5.3 & 1.8 \\
\hline
\end{tabular}

${ }^{\mathrm{ns}}$ not significant at $5 \%$ by the $\mathrm{F}$ test $/ *$ Significant at $5 \%$ by the $\mathrm{F}$ test.

TABLE 2 - Mean chroma and skin color hue, fresh mass, length and diameter values of 'Prata-Anã', 'BRS Platina', 'Fhia-18', 'BRS Conquista' BRS Tropical 'bananas produced in organic system. Mean of non-significant variable (skin color luminosity). Point of harvest. Nova Porteirinha - MG, 2014.

\begin{tabular}{c|ccccc}
\hline & \multicolumn{5}{c}{ Characteristics } \\
\hline Variety & Chroma $\left(\mathrm{C}^{*}\right)$ & Hue angle $\left({ }^{\circ}\right.$ hue $)$ & Fresh mass $(\mathrm{g})$ & Length $(\mathrm{cm})$ & Diameter $(\mathrm{mm})$ \\
\hline Prata-Anã & $44.99 \mathrm{~A}$ & $117.06 \mathrm{BC}$ & $115.76 \mathrm{~B}$ & $18.37 \mathrm{BC}$ & $37.72 \mathrm{C}$ \\
BRS Platina & $41.46 \mathrm{~B}$ & $115.86 \mathrm{C}$ & $201.04 \mathrm{~A}$ & $21.88 \mathrm{~A}$ & $46.87 \mathrm{~A}$ \\
Fhia - 18 & $41.70 \mathrm{~B}$ & $117.87 \mathrm{AB}$ & $181.02 \mathrm{~A}$ & $20.77 \mathrm{AB}$ & $41.58 \mathrm{~B}$ \\
BRS Conquista & $43.35 \mathrm{AB}$ & $118.74 \mathrm{~A}$ & $82.35 \mathrm{C}$ & $13.92 \mathrm{D}$ & $35.26 \mathrm{D}$ \\
BRS Tropical & $44.45 \mathrm{~A}$ & $117.67 \mathrm{AB}$ & $120.62 \mathrm{~B}$ & $16.83 \mathrm{C}$ & $40.79 \mathrm{~B}$ \\
\hline d. m. s. & 1.9439 & 1.4869 & 28.4076 & 2.6295 & 1.9692 \\
\hline \multicolumn{7}{c}{ Non-significant variable } & \multicolumn{5}{c}{} \\
\hline \multicolumn{2}{l}{ Luminosity } & 59.3 &
\end{tabular}

Means followed by the same letter in the column do not differ from each other by the Tukey test at $5 \%$.

TABLE 3-Analysis of variance for variables of mature organic banana varieties. Nova Porteirinha - MG, 2014.

\begin{tabular}{c|ccccccccccc}
\hline F.V. & D. F. & $\mathrm{L}^{*}$ & $\mathrm{C}^{*}$ & ${ }^{\circ}$ hue & $\begin{array}{c}\text { Dropping } \\
\text { resistance }\end{array}$ & Firmness & $\begin{array}{c}\text { Soluble } \\
\text { solids }\end{array}$ & $\mathrm{pH}$ & $\begin{array}{c}\text { Titratable } \\
\text { acidity }\end{array}$ & $\begin{array}{c}\text { Pulp/ } \\
\text { skin }\end{array}$ & ratio \\
\hline Variety & 4 & $54.2^{*}$ & $29.3^{\text {ns }}$ & $1392.8^{*}$ & $116.1^{*}$ & $4.1^{*}$ & $1.3^{\text {ns }}$ & $0.4^{\text {ns }}$ & $0.5 \mathrm{E}^{\text {02ns }}$ & $7.0^{*}$ & $60.1^{\text {ns }}$ \\
Residue & 10 & 11.9 & 10.6 & 2.8 & 1.1 & 0.2 & 2.9 & 0.2 & $0.2 \mathrm{E}^{-02}$ & 0.1 & 30.2 \\
\hline V.C. $(\%)$ & & 4.8 & 6.7 & 1.9 & 16.5 & 11.1 & 14.2 & 3.2 & 15.4 & 10.6 & 14.8 \\
\hline
\end{tabular}

${ }^{\mathrm{ns}}$ not significant at $5 \%$ by the $\mathrm{F}$ test $/ *$ Significant at $5 \%$ by the $\mathrm{F}$ test.

TABLE 4- Average values of luminosity $(\mathrm{L} *),{ }^{\circ}$ hue, dropping resistance (Dr), firmness and pulp / skin ratio of 'Prata-Anã', BRS Platina, Fhia-18, BRS Conquista and BRS Tropical bananas produced in organic system. Mean of non-significant variables (chroma, soluble solids, $\mathrm{pH}$, titratable acidity and ratio). Mature fruits. Nova Porteirinha - MG, 2014.

\begin{tabular}{l|ccccc}
\hline Variety & $\mathrm{L}^{*}$ & ${ }^{\circ}$ hue & $\mathrm{Dr}(\mathrm{N})$ & Firmness (N) & Pulp/skin \\
\hline Prata-Anã & $71.84 \mathrm{AB}$ & $93.99 \mathrm{AB}$ & $3.4 \mathrm{BC}$ & $5.98 \mathrm{~A}$ & $2.69 \mathrm{C}$ \\
BRS Platina & $64.73 \mathrm{~B}$ & $97.84 \mathrm{~A}$ & $4.05 \mathrm{BC}$ & $3.52 \mathrm{~B}$ & $1.77 \mathrm{D}$ \\
Fhia - 18 & $72.79 \mathrm{AB}$ & $93.36 \mathrm{AB}$ & $5.7 \mathrm{~B}$ & $3.24 \mathrm{~B}$ & $1.94 \mathrm{CD}$ \\
BRS Conquista & $76.37 \mathrm{~A}$ & $91.44 \mathrm{~B}$ & $17.11 \mathrm{~A}$ & $4.15 \mathrm{~B}$ & $3.92 \mathrm{~B}$ \\
BRS Tropical & $72.46 \mathrm{AB}$ & $46.26 \mathrm{C}$ & $1.28 \mathrm{C}$ & $3.15 \mathrm{~B}$ & $5.42 \mathrm{~A}$ \\
\hline d. m. s. & 9.2563 & 4.5159 & 2.7889 & 1.1912 & 0.8944 \\
\hline Non-significant variables & & & & & \\
Chroma & 48.19 & & & & \\
Soluble solids ( ${ }^{\circ}$ Brix) & 11.96 & & & \\
pH & 4.58 & & & & \\
Titratable acidity (\%) & 0.31 & & & & \\
Ratio & 39.1 & & & & \\
\hline
\end{tabular}

Means followed by the same letter in the column do not differ from each other by the Tukey test at $5 \%$. 


\section{CONCLUSIONS}

Varieties differ more by the physical characteristics (skin color, size, dropping resistance, firmness and pulp / skin ratio) in relation to chemical characteristics.

At the point of harvest, 'BRS Conquista', 'BRS Tropical' and 'Fhia-18' fruits show more intense green skin color. 'BRS Conquista' bananas have lower fresh mass, smaller length and diameter than the other varieties. 'BRS Platina' fruits have higher fresh mass, length and diameter;

Mature 'Prata-Anã', 'BRS Platina', 'Fhia 18', 'BRS Conquista' and 'BRS Tropical' fruits do not present difference in soluble solids content, $\mathrm{pH}$, titratable acidity and ratio; 'BRS Platina' fruits had more intense yellow skin color and lower pulp / skin ratio. 'BRS Conquista' fruits showed higher dropping resistance and 'BRS Tropical' fruits are less resistant. 'Prata-Anã' fruits showed greater firmness.

\section{ACKNOWLEDGMENTS}

To Banco do Nordeste for the financing of the Project. To Fapemig for financial assistance and research grants to carry out this work.

\section{REFERENCES}

BORGUINI, R.G.; TORRES, E.A.F.S. Alimentos orgânicos: qualidade nutritiva e segurança do alimento. Segurança Alimentar e Nutricional, Campinas, v.13, n.2, p.64-75, 2006.

BRASIL. Ministério da Agricultura, Pecuária e Abastecimento. Regulamento técnico para os sistemas orgânicos de produção. Instrução normativa $n^{\circ} 46$, de 6 de outubro de 2011 . Disponível em: <http://www.agricultura.gov.br/ arq editor/file/Desenvolvimento Sustentavel/ Organicos/Legislacao/Nacional/Instrucao Normativa $\mathrm{n} 0046$ de 06-10-2011 regulada pela IN 17.pdf >. Acesso em: 1 dez. 2015.)

BRASIL. Ministério da Agricultura, Pecuária e Abastecimento. Instrução Normativa $n^{\circ} 17$, de 18 de junho de 2014. Regulamento técnico para os sistemas orgânicos de produção. Diário Oficial Oficial [da República Federativa do Brasil], Brasília, DF, n.116, 20 jun. 2014. Seção I, p.32.
CARVALHO, A.V.; SECCADIO, L.L.; MOURÃO JUNIOR, M.; NASCIMENTO, W.M.O. Qualidade pós-colheita de cultivares de bananeira do grupo 'maçã', na região de Belém - PA. Revista Brasileira de Fruticultura, Jaboticabal, v.33, n.4, p.1095-102, 2011.

CASTRICINI, A.; SANTOS, L.O.; DELIZA, R.; COELHO, E.F.; RODRIGUES, M.G.V. Caracterização pós-colheita e sensorial de genótipos de bananeiras tipo Prata. Revista Brasileira de Fruticultura, Jaboticabal v.37, n.1, p.20-31, 2015.

CEAGESP. Programa Brasileiro para a Modernização da Horticultura \& Produção Integrada de Frutas. Normas de classificação de banana. São Paulo, 2006. (Documentos, 29). Disponível em: http://www. hortibrasil.org.br/jnw/images/stories/folders/banana. pdf. Acesso em: 05 jun. 2015.

CORDEIRO, Z.J.M.; VIEIRA, J.F.; MATOS, A.P.de ; SILVA, S. de O. Resistência de genótipos tetraploides de bananeira à Sigatoka-amarela. In: REUNIÃO INTERNACIONAL ACORBAT, 17., 2006, Santa Catarina. Anais ... Santa Catarina: Epagri, 2006. p.433-6.

COSTA, F.da S.; COELHO, E.F.; BORGES, A.L.; PAMPONET, A.J.M.; SILVA, A. dos A.S.M. da; AZEVED O.N.F. de. Crescimento, produção e acúmulo de potássio em bananeira 'Galil 18' sob irrigação e fertilização potássica. Pesquisa Agropecuária Brasileira, Brasília, DF, v.47, n.3, p.409-416, 2012.

DAMATTO JÚNIOR, E.R.; CAMPOS, A.J. de; MANOEL, L.; MOREIRA, G.C.; LEONEL, S.; EVANGELISTA, R.M. Produção e caracterização de frutos de bananeira 'Prata-Anã' e 'Prata-Zulu'. Revista Brasileira de Fruticultura, Jaboticabal, v.27, n.3, p.440-3, 2005.

DONATO, S.L.R.; OLIVEIRA e SILVA, S.de.; LUCCA FILHO, O.A.; LIMA, M.B.; DOMINGUES, H.; ALVES, J.da S. Comportamento de variedades e híbridos de bananeira (Musa spp.), em dois ciclos de produção no sudoeste da Bahia. Comunicação Científica. Revista Brasileira de Fruticultura, Jaboticabal, v.28, n.1, p.139-44, 2006.

IBGE. Sistema IBGE de recuperação automática - Sidra. Disponível em: http://www.sidra.ibge.gov. br/bda/prevsaf/default.asp. Acesso em: 18 mar.2015. 
INSTITUTO ADOLFO LUTZ. Normas analíticas do Instituto Adolfo Lutz. Métodos químicos e físicos de análise de alimentos. 3.ed. São Paulo, 1987.

LÉDO, A.da S.; SILVA JUNIOR, J.F.da; LEDO, C.A.da S.L.; SILVA, S.de O. Avaliação de genótipos de bananeira na região do baixo São Francisco, Sergipe. Revista Brasileira de Fruticultura, Jaboticabal, v.30, n.3, p.691-5, 2008.

LOESECKE, H.W.V. Bananas: chemistry, physiology, and technology. New York: Chapman and Hall, 1950. 189p.

MATSUURA, F.C.A.U.; COSTA, J.I.P.; FOLEGATTI, M.I.S. Marketing de banana: preferências do consumidor quanto aos atributos de qualidade dos frutos. Revista Brasileira de Fruticultura, Jaboticabal, v.26, n.1, p.48-52, 2004.

OLIVEIRA, C.G.DE; DONATO, S.L.R.; MIZOBUTSI, G.P.; SILVA, J.M.da; MIZOBUTSI, E.H. Características pós-colheita de bananas 'PrataAnã' e 'BRS Platina' armazenadas sob refrigeração. Revista Brasileira de Fruticultura, Jaboticabal, v.35, n.3, p.891-7, 2013.

OLIVEIRA, C.G.de; SANCHÊS, C.L.G.; PINHEIRO, J.M.da S.; MIZOBUTSI, G.P.; DONATO, S.L.R.; DAMASCENO, J.E.A. Caracterização físicoquímica e sensorial de frutos de banana 'Prata-Anã' e PA 42-44. In: SIMPÓSIO BRASILEIRO SOBRE BANANICULTURA, 7., 2010b, Registro. Anais ... Registro: SBF, 2010a. p.52-6.

OLIVEIRA, G.H.H.; CORRÊA, P.C.; BAPTESTINI, F.M.; FREITAS, E.L.; VASCONCELLOS, D.S.L. Controle do amadurecimento de goiabas 'Pedro Sato' tratadas por frio. Enciclopédia Biosfera, Goiânia, v.6, n.9, p.1-15, 2010 b.
PEREIRA, J.C.R.; GASPAROTTO, L. BRS conquista: nova cultivar de bananeira para o agronegócio da banana no Brasil. Manaus: Embrapa Amazônia Ocidental, 2008. 2p. (Comunicado Técnico, 60).

PIMENTE L, R.M.de A.; GUI MARAES, F.N.; SANTOS, V.M.; RESENDE, J.C.F.de. Qualidade pós-colheita dos genótipos de banana PA42-44 e Prata-Anã cultivados no Norte de Minas Gerais.

Revista Brasileira de Fruticultura, Jaboticabal, v.32, n.22, p.407-413, 2010.

RAMOS, D.P.; LEONEL, S.; MISCHAN, M.M. Caracterização físico-química dos frutos de genótipos de bananeira produzidos em Botucatu-SP. Ciência e Agrotecnologia, Lavras, v.33, p.1765 -70, 2009. Edição especial.

RIBEIRO, L.R.; OLIVEIRA, L.M.de; SILVA, S.de O.; BORGES, A.L.Caracterização física e química de bananas produzidas em sistemas de cultivo convencional e orgânico. Revista Brasileira de Fruticultura, Jaboticabal, v.34, n.3, p.774-82, 2012.

SAEG. Sistema para análises estatísticas, Versão 9. Viçosa: Fundação Arthur Bernardes, 2007.

TEIXEIRA L.J.Q.; POLA C.C.; JUNQUEIRA; M.da S.; MENDES, F.Q.RODRIGUES JUNIOR, S.Cenoura (Daucus carota): processamento e composição química. Enciclopédia Biosfera, Goiânia, v.7, n.12, p.1, 2011.

TRIGO, J.M.; ALBERTINI, S.; SPOTO, M.H.F.; SARMENTO, S.B.S.; LAI REYES, A.E.; SARRIÉS, G.A. Efeito de revestimentos comestíveis na conservação de mamões minimamente processados. Brazilian Journal of Food Technology, Campinas, v.15, n.2, p.125-33, 2012. 